\title{
DIPLOMATIC RELATIONS BETWEEN ACEH AND TURKEY DURING THE REIGN OF SULTAN ALAUDDIN MANSUR SHAH (1577-1585 / 1586)
}

\author{
HUBUNGAN DIPLOMATIK ANTARA ACEH DAN TURKI PADA MASA \\ KESULTANAN ALAUDDIN MANSUR SHAH (1577-1585/1586)
}

\author{
Khairul Nizam bin Zainal Badri \\ Madrasah Pra Tahfiz Al Mansoorah, Puchong, Selangor, Malaysia \\ Email: knizamzbmaptam@gmail.com \\ DOI: $10.36424 / j p s b . v 7 i 1.256$
}

Naskah Diterima: 12 April 2021 Naskah Direvisi: 13 Mei 2021

Naskah Disetujui: 13 Mei 2021

\begin{abstract}
Aceh is regarded as the strongest ally of the Ottomans in the east, in the $16^{\text {th }}$ century and $17^{\text {th }}$ century AD. At that time, the two governments exchanged gifts with each other, and benefited together; whether in the form of trade, or in the form of technology and the military. The historical record notes that Aceh started making official relations with the Ottomans during the reign of Sultan Salahuddin, which is the $2^{\text {nd }}$ in the Sultanate of Aceh. Yet to be studied in this paper is that the establishment of diplomatic relations between Aceh and Turkey during the reign of Sultan Alauddin Mansur Shah. Remarkably, Sultan Alauddin Mansur Shah hailed from Perak, but was crowned the $8^{\text {th }}$ Ruler of Aceh. This qualitative study uses the library approach entirely to highlight the role and contribution of Sultan Alauddin Mansur Shah in efforts to strengthen cooperation between Aceh and Turkey. With the help of the Ottomans, he launched an attack on the Portuguese in Melaka. Aceh's strength even feared by the Portuguese authorities in Goa, India, forcing them to seek assistance from Lisbon. In conclusion, Sultan Alaudin Mansur Shah not only gained recognition from the Ottoman government but also succeeded in upholding the greatness of Islam; when reviving the trade routes of Muslims and looking after the welfare of Muslims in the archipelago.
\end{abstract}

Keywords: Sultan Alauddin Mansur Shah, Aceh, Turkish, Ottoman, Melaka 


\begin{abstract}
Abstrak
Aceh dianggap sebagai sekutu terkuat Utsmaniyah di Timur pada abad 16 dan 17. Pada saat itu, kedua pemerintahan tersebut saling bertukar kado, dan saling menguntungkan baik dalam bentuk perdagangan, maupun dalam bentuk teknologi dan militer. Catatan sejarah menyebutkan bahwa Aceh mulai menjalin hubungan resmi dengan Utsmaniyah pada masa pemerintahan Sultan Salahudin yang merupakan Sultan ke-2 dalam Kesultanan Aceh. Namun yang akan dikaji dalam makalah ini adalah hubungan diplomatik resmi antara Aceh dan Turki pada masa pemerintahan Sultan Alaudin Mansur Shah. Istimewanya Sultan Alaudin Mansur Shah dari Perak saat dia datang, tetapi dinobatkan sebagai Sultan Aceh ke-8. Kajian ini merupakan pendekatan kualitatif untuk menyoroti peran dan kontribusi Sultan Alaudin Mansur Shah dalam upaya memperkuat kerja sama antara Aceh dan Turki. Dengan bantuan Utsmaniyah, dia melancarkan serangan terhadap Portugis di Melaka. Kekuatan Aceh bahkan ditakuti oleh otoritas Portugis di Goa, India, memaksa mereka untuk mencari bantuan dari Lisbon. Kesimpulannya, Sultan Alaudin Mansur Shah tidak hanya mendapat pengakuan dari pemerintahan Utsmaniyah tetapi juga berhasil menegakkan daulah Islamiyah dengan menghidupkan kembali jalur perdagangan umat Islam dan menjaga kesejahteraan umat Islam di Nusantara.
\end{abstract}

Kata Kunci: Sultan Alaudin Mansur Shah, Aceh, Turki, Uthmaniyyah, Melaka

\title{
INTRODUCTION
}

History records that Sultan Alaudin Riayat Shah Al-Qahhar (1537-1568), is the most prominent Malays who established diplomatic relations with the Ottoman Empire in Turkey. The reciprocal relationship allows Aceh to receive assistance in the form of military, weapons technology, engineering and scholars. Another ruler of Aceh which often makes diplomatic relations with Turkey was Sultan Alaudin Mansur Shah (1577-1585 / 86). However, his stature is rarely discussed compared to Sultan Alaudin Riayat Shah Al-Qahhar. In fact, just like Sultan Alaudin Riayat Shah, Sultan Alaudin Mansur Shah has also received recognition from the Ottoman Empire. On the initiative of the Sultanate of Aceh's relations with the Ottoman Empire, the army of Aceh was allowed to use the flag of the Ottoman Empire, which is the sign that Aceh is under the protection of the Ottoman Empire (Hassan, 2004). In another narration, thanks to the efforts of 
Sultan Alauddin Mansur Shah establish diplomatic relations with Turkey, the armed force of Aceh has been granted consent to use the Turkish flag to monitor the coast of Malaya and the archipelago (Zainuddin H. M., 1957:32).

Given that not much academic research has been done on Sultan Alaudin Mansur Shah; then this paper seeks to initiate further research on the role played by Sultan Alauddin Mansur Shah in establishing diplomatic relations between Aceh with Turkey. Also noteworthy is his contribution in promoting bilateral relations between the two kingdoms, and significant to the rule of Islam in Aceh.

Sultan Alaudin Mansur Shah is the object of study in this writing because of the uniqueness that he has in terms of his personality either externally or internally. Outwardly, he is described as a pious man in life. As for the interior, he did not have a drop of blood from Aceh; instead came from the state of Perak. Thus, the main objective of the study in this paper is to look at the leadership of Sultan Alauddin Mansur Shah in generating diplomatic relations between Aceh with Turkey, even though he was not born in Aceh.

\section{METHODOLOGY}

This qualitative study uses the full literature method for the purpose of collecting data. In data collection, the documents are investigated one by one so that facts can be found according to the scope of the discussion. Furthermore, the facts are compared and arranged in chronological order. Analysis of the data was then made based on the chronology and themes of the study. Further, the discussion was formulated to either meet the objectives of the study or otherwise.

\section{DISCUSSION}

\section{Early history of formal relations}

Cooperative relations between Aceh and Turkey believed to have started officially, at the time of the $2^{\text {nd }}$ Ruler of Aceh, Sultan Salahudin, who ruled from 1530 - 1537. He took over the government of Aceh after the death of his father, Sultan Ali Mughayat Shah, who is considered the founder of the Sultanate New 
Aceh; having succeeded in uniting the kingdoms of Pasai, Pidie and Daya (Zainuddin, 1962:395-396).

Turkish Ottoman ruler, Sultan Sulaiman ruled from 1520 - 1566, has sent a group of scholars, officials and the military to help the Aceh government to strengthen political stability in Southeast Asia; as well as being the strongest ally of the Ottoman Empire. One cleric sent to Aceh is Muttalib Ghazi, known by people in Aceh as Tengku Bitay. Clergy residence has become the settlements of the Turks, who later became a permanent resident of Aceh, which is now located in the District of Jaya Baru. The closeness of his relationship with Sultan Salahuddin can be seen when the two were buried in Kampung Bitai. After the death of Sultan Salahuddin, Shaykh Muttalib bequeathed to the people of Aceh to bury him next to the Sultan Salahuddin after his death, and the will was then executed by the people of Aceh. Under the influence of these scholars, intellectual activities in Aceh began to grow. While officials and Turkish troops sent to Aceh to assist officials and military commander of Aceh to establish the academy and build a weapon. The technology and engineering division was created for that purpose (Melihat Jejak Turki di Gampong Bitai, 2021).

Sheikh Mutalib is narrated to have come from Palestine and then settled in Istanbul, Turkey (Damhuri, 2020). His lineage is as follows, Syakir Jundi $\rightarrow$ Muhammad Jamil Ghazi $\rightarrow$ Abdul Aziz Ghazi $\rightarrow$ Saidam Ghazi $\rightarrow$ Sirikhu Ghazi $\rightarrow$ Muhammad Saleh Ghazi $\rightarrow$ Ilyas Ghazi $\rightarrow$ Ishak Ghazi $\rightarrow$ Ahmad Ghazi $\rightarrow$ Rustam Ghazi $\rightarrow$ Basyah Ghazi $\rightarrow$ Rauf Ghazi $\rightarrow$ Mustafa Ghazi $\rightarrow$ MUTALIB GHAZI (scholar of Turkey who first come to Aceh) $\rightarrow$ Jalal Basyar Ghazi $\rightarrow$ Ismail Ghazi $\rightarrow$ Harun Ghazi $\rightarrow$ Abdul Jalal $\rightarrow$ Abdullah Tamim Ghazi $\rightarrow$ Faqih Seri Raja Faqih $\rightarrow$ Syeikh Abdul Rahman $\rightarrow$ Syeikh Ismail $\rightarrow$ Teungku Haji Abdul Aziz $\rightarrow$ Teungku Haji Mahmud Juned $\rightarrow$ Teungku Haji Razali died in 1987 (Nasir, 2010).

Cooperative relations with Turkey were continued by Sultan Salahuddin's successor, Sultan Alaudin Riayat Shah Al-Qahhar. He, who was the younger 
brother of Sultan Salahuddin, was the first figure to attack the Portuguese fort in Melaka in 1537. He also made two other attacks in 1547 and 1568 on the Portuguese in Melaka (Villers, 2001:81).

Probably an attack made in 1568; was the largest attack carried out by Sultan Alaudin Riayat Shah Al-Qahhar on the Portuguese. This was because he had enlisted the help of the Ottoman ruler, Sultan Selim II in 1567 to attack the Portuguese in Melaka. In return, Sultan Selim II was sent 15 ships were accompanied by 400 Turkish military to help Aceh, directing the attack towards Melaka (Villers, 2001:78).

In another record, Turkey once sent two ships in 1565 when the Ottomans were under the rule of Sultan Sulaiman. It is said that the Turkish army has brought together the Turkish flag and cannon, known as lada secupak (pepper quart) to Aceh (Maksudoglu, 1999:133-134).

It is reported that Sultan Selim II did not ask for a reply in the form of tribute from Aceh; on the military aid extended. Instead he just ordered all the people of Aceh to celebrate the birthday of the Prophet Muhammad SAW with a festive celebration. Since then, the people of Aceh are always celebrating the birthday of the Prophet Muhammad SAW on a large scale (Batubara, 2020:5). Perhaps on the basis of a deep love for the Prophet Muhammad SAW, which have led to Sultan Iskandar Thani, $13^{\text {th }}$ Ruler of Aceh; built the Dewala Kandang and ordered anyone who entered it to recite salawat first. Interestingly, the construction of Dewala Kandang; which is now classified as one of the beautiful gardens in Aceh have been executed by construction experts, and technology from Turkey to serve the Sultanate of Aceh at the time (Yusof, 2020).

\section{The Portuguese threat}

By the $16^{\text {th }}$ century, the Portuguese became the fiercest rivals on almost all Muslim governments around the world including the Ottoman and Aceh. The Ottomans, the largest Islamic kingdom at the time were the most notable once felt its effects. The opening of the Cape of Good Hope as a result of Vasco da Gama's 
exploration in 1498, has created a new route for the Portuguese in particular, and Europe in general to enter trade areas in the Red Sea and Indian Ocean (Maksudoglu, 1999:131).

The exploration has not only competed to seize trade areas, but has also sparked conflicts in strategic areas such as in Basrah, Hijaz and Yemen. What is certain is that this clash has involved two great European powers namely the Portuguese and the Ottomans. By 1505, the Portuguese mission to block trade routes through the Middle East to Europe was almost successful. In other words, the Middle East route that had long been dominated by the Ottomans was blocked by the Portuguese. Trade products such as spices are almost no longer available in the markets of Alexandria, Cairo and Beirut. Such abrupt changes have led to a severe downturn to the Middle East economy (Arshad, 2004:9).

The thing that worried the Ottomans the most was the rumors that the Portuguese would conquer Jeddah. The news, if true, will surely raise concerns about the situation in the Holy Land. The Portuguese had already attacked the Ottoman defenses at Suez, had even managed to burn the Sina Tour in 1543. The Ottoman navy under the leadership of Piri Reis had successfully prevented the Portuguese from attempting to conquer Aden and Muscat in 1551. At that time, the Ottoman forces with a strength of 30 the ships faced 70 Portuguese ships. Murad Reis took over the task of Piri Reis to fight the Portuguese who were trying hard to take control of Hurmuz. After that, there was a naval clash under the leadership of Ali Reis with a force of 15 ships against 25 Portuguese ships on the Basrah and Muscat routes. He managed to hijack 4 ships and sink most of the others. A major storm had swept Ali Reis to India and stayed there for three years (Maksudoglu, 1999:131-133).

Recognizing the importance of the Red Sea as the most important route for Muslims, the Ottoman government devised a strategy to build a canal in Suez. With the existence of the canal later, the relationship of the Ottoman government with other Islamic kingdoms in the East became easier. In addition, the canal also 
facilitated the Ottoman government to supervise and guard the Holy Land area from being threatened by the enemy, and facilitated the movement of pilgrims. This was because pilgrim ships from the East were often disturbed by the Portuguese who had taken control of the Indian Ocean. The study was carried out in 1568 but its construction could not be continued most likely due to factors of war, conflict and so on. But Suez role as a liaison between the Ottoman Empire in the East, especially in Aceh continues to perform well. For example, all goods sent by the Ottoman government to Aceh, is through Suez (Maksudoglu, 1999:140).

\section{The rule of Sultan Alaudin Mansur Shah}

After besieging Melaka for a month and almost winning, Sultan Alaudin Riayat died. The incident occurred in 1568. In the absence of the skipper, Aceh army was forced to retreat back to their homeland. After that Aceh suffered an internal crisis in the past ten years resulting in Aceh bereft of a credible government (Zainuddin, 1962:398). In an unstable political situation, suddenly a prince of Perak, was appointed as the new Sultan. His Majesty is Sultan Alaudin Mansur Shah who has traces of descent from the Sultanate of Melaka. He, however, has been married to Queen Aceh (Djajadiningrat, 1982:28).

However, Aceh still seen as the strongest power in Southeast Asia that could rival the Portuguese whether in trade or in the mission of spreading the religion. The mission of spreading Christianity was in fact the main agenda of the Portuguese, and then followed by trade. To reinforce the agenda, the Portuguese sent Padroado Real to Melaka (Villers, 2001:80). When Sultan Alauddin Mansur Shah took over, circa 1577, Aceh had conquered most of Sumatra and the Malay Peninsula. To offset the power of Aceh, the Portuguese has appointed a new commander, named Tristao Vaz de Vieiga (Villers, 2001:81).

Sultan Alaudin Mansur Shah continued diplomatic relations with Turkey as had been done by previous governments. In the Portuguese record, Aceh and Turkey mutually exchanged gifts. Aceh presented Turkey with gold, precious 
stones, spices and perfumes; while Turkey provided military assistance in the form of weapons, expert manpower and protection. From another angle, Aceh helped Turkey to redevelop the spice trade routes to the Middle East that had been blocked by the Portuguese (Saputro, 2017).

Aceh then still recognized the sovereignty of the Ottoman Empire as the greatest Islamic empire that housed and protected the Islamic kingdoms in the world. However, as emphasized by Sultan Alaudin Riayat Shah Al-Qahhar in his letter to Sultan Selim II, Turkey needs to pay attention to issues occurring in the East especially in the Indian Ocean and the Straits of Malacca; in accordance with its position as the largest Islamic government. From another angle, the Ottoman power was seen to be affected after the death of Sultan Sulaiman in 1566. The conflict between the Ottomans and the Safavids also affected the fall of the Empire. Aceh versa managed to increase its influence in the East, even recognized by the Portuguese as their main rivals. Although Aceh has had a big name in the East, the Sultan of Aceh still wants to continue working with Turkey. Indirectly, the establishment of Aceh has helped improve the image of Turkey as other major powers, especially Europe, saw Turkey and Aceh as one joint force, which is very strong, which controls military operations in Europe and Asia (Ozay, 2011:278).

The success of Aceh revived trade routes Muslims between the Red Sea and the Indian Ocean, have also helped reviving Turkey's reputation as one of the great powers in the economic field in Europe. Through Aceh, merchandise from Asia were brought and traded at Alexandria, Egypt, Venice, Italy (Ozay, 2011:279).

The year 1582 is perhaps the most important year to remember during the reign of Sultan Alaudin Mansur Shah. This is because in that year, Sultan Alaudin Mansur Shah had mobilized a very large force to attack the Portuguese. The Ottoman government also helped Sultan Alaudin Mansur Shah when they sent 160 ships to bomb Melaka (Casale, 2007:284). 
The attack was probably linked to an attempt to distract the Portuguese who were said to have planned to attack Jeddah. At that time, the Portuguese already had a permanent base on Socotra Island, Yemen (Casale, 2007:289).

The name of Sultan Alaudin Mansur Shah is recorded in a Portuguese manuscript entitled Historia de services com martirio de Luis Monteiro Coutinho compiled by Manoel Godinho de Eredia in 1615 which is closely related to the attack that took place in 1582. At that time Melaka was ruled by Roque de Mello Pereira, who was appointed to replace Dom Joao da Gama in 1581. Sultan Alaudin Mansur Shah came to attack Melaka with a large force, involving 7 large ships, 40 junks and 150 small-sized warships (Subrahmanyam, 2009:43).

Clash erupts between Aceh fleet with Portuguese warships led by Luis Monteiro Coutinho. Although Melaka could not be conquered by Aceh at that time, the captain of the Portuguese were captured and brought back to Aceh. The event took place on February 6, 1583 (Subrahmanyam, 2009: 44).

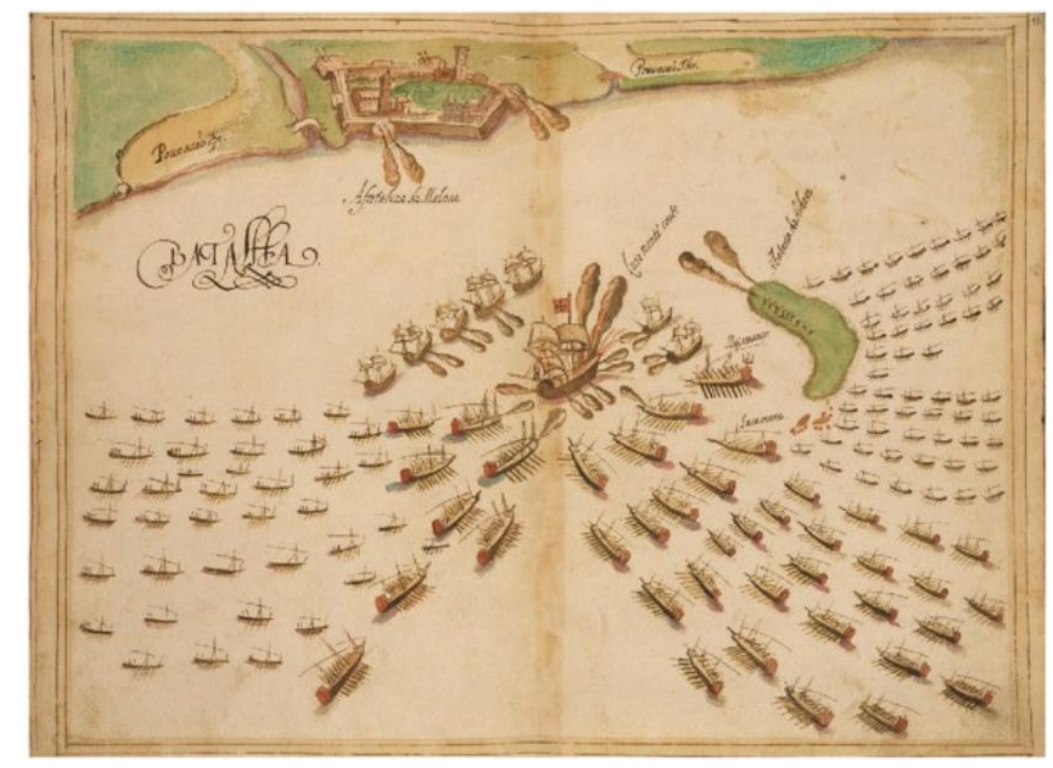

Figure 1: Sketch of the battle between the forces of Monteiro Coutinho and the fleet of Aceh as found in the manuscripts written by Eredia (Subrahmanyam, 2009:45)

The events of the attack are also recorded in a Portuguese manuscript entitled Decada Decima da Asia written by Diogo do Couto. According to him, 
the attack began on August 22, 1582. Aceh military forces invaded Malacca with a force of 150 light vessels, large vessels and 7 seven junks. Aceh military forces, however, reported to have been blocked by the armed forces of the Portuguese, led by Luis Coutinho Monteiro after an explosion on board. Some Portuguese troops, was captured by the Aceh army, and then brought back to Aceh (Subrahmanyam 2009: 46).

So many Portuguese became prisoners of war; and most of them had converted to Islam and married locals. History records that the Portuguese people living in Aceh is said to have started in the reign of Sultan Salahuddin. When Aceh attack the Keluang kingdom; which was a neighbor of the Daya Kingdom, the Portuguese army had come to help Keluang. Many Portuguese armies became prisoners of war to Aceh, after Keluang was defeated in battle (Fikrie \& Azis, 2017).

Portuguese people in Aceh are mostly concentrated in Lamno located about $86 \mathrm{~km}$ from Banda Aceh. Among the villages they inhabit are in Kuala Daya, Lambeuso, Ujong Meuloh, Geu, Bahagia, Teumareum, Gle Jong and Mukhan (B1, 2011).

Back to Sultan Alauddin Mansur Shah, his ability to renew diplomatic relations with Ottoman much appreciated by Turkey. On that basis, the Ottoman government bestowed a star of honor on him. The award is not just an investiture ceremony to Aceh, but also actually become a symbol of the power of the Sultanate of Aceh's hard to spread Islam in the East (Zainuddin, 1962: 301).

At the same time, the Turkish influence began to permeate the culture of Aceh itself especially from a cultural point of intellectuality. Manuscripts containing Middle Eastern-themed texts such as Hikayat Iskandar Zulkarnain, Hikayat Amir Hamzah and Hikayat Muhammad Hanafiyyah began to replace manuscripts mixed with Hindu epics and myths. Similarly, Hikayat Merong Mahawangsa, which is very famous in Malaya, also has a very strong Turkish influence such as the lineage of the Malay Rulers who have a relationship with the 
King of the Romans, which refers to the King of Turkey. Although the hikayat tends to narrate the lineage of the Rulers of Kedah; however, there is also the story of how the state of Perak got its name. The story seems to signal the existence of Perak's connection with the Roman kingdom as well (Burhanudin, 2016:378-381).

The Ottomans also never fail to send scholars to Aceh. Among the wellknown scholar of Turkish origin who had served the people of Aceh are Sheikh Daud ibn Ismail Al-Rumi. He lived during the reign of Sultanah Safiatuddin Tajul Alam, who ruled around 1641 to 1675 (Hassan, 2004:36).

The use of musical instruments also probably has a strong connection with Turkish influence. For example, Sultan Selim II when sent gifts to Aceh, also included a trumpet made of silver, as narrated by Sheikh Ahmad bin Muhammad Zain Al-Fathani`s in his article titled Hadiqat Al-Azhar wa Al-Riyahin (Hassan, 2004:37).

Sultan Alauddin Mansur Shah is reported to have been killed in Aceh when planning to attack kingdom of Johor and Malacca in 1586. The attack on the Johor's kingdom implemented, as the government is rumored to have collaborated with the Portuguese. In addition, the main reason for his attack on Malacca is to ensure the rule of Islam, shining again in Tanah Melayu (Zainuddin H. M., 1957). In another narration, he was murdered in Aceh after returning from Perak, after visiting his brother (Winstedt \& Wilkinson, 1974:32).

His assassination is said to have something to do with the nobility descended from Sultan Ali Mughayat Shah who wanted to regain power. After his death, there was a chaos and power struggle (Zainuddin H., 1962:400).

\section{Turkey under the reign of Sultan Murad III and Its Influence to Aceh}

The Turkish ruler of the same time as Sultan Alauddin Mansur Shah, was Sultan Murad III, who ruled from 1574 to 1595 . He was the son of Sultan Selim II and Queen Nur Banu (Cecilia-Venier Baffo). The character of Sultan Murad III is said to be similar to that of Sultan Alauddin Mansur Shah because they are both 
pious in living life. Just as Sultan Alauddin Mansur Shah loved the scholars, so did Sultan Murad III who liked to be with the scholars. The effect of the attitude of liking to be side by side with the scholars enabled him to master the Arabic and Persian languages as well as expertise in the field of tasawwuf. He ordered his army to maintain the boundaries of sharia, for example, not to get involved with alcohol, especially among the elite. His Majesty was involved in a military expedition by conquering the Caucasian territory consisting of Azerbaijan, Kyrgyzstan, Georgia, Tajikistan and other surrounding countries. He also opened the doors of trade with other European countries such as France, Hungary and the British (Bastoni, 2008:262-265).

It is narrated that the Ottoman conquest during the reign of Sultan Selim II, who was the father of Sultan Murad III began to decline compared to previous rulers (Maksudoglu, 1999:136). But in terms of the development of science and technology, it is growing.

Among the fields of knowledge that developed rapidly during the reign of Sultan Murad III were medicine, astronomy and the production of manuscripts. The field of medicine progressed after a large medical complex was built in 1550 . The construction was inspired by Sultan Sulaiman I, and the complex was named the Sulaimaniyyah Complex in honor of his name. The complex consists of a hospital, cafeteria, rehabilitation center, pharmacy, and medical school known as Sulaimaniyah School of Medicine. Students who study medicine are exposed to theory and experience in the field. Sulaimaniyyah School of Medicine also keeps a collection of past medical manuscripts for reference by teachers and students. Students are also required to master the fields of religion, philosophy and Arabic language. The establishment of such medical schools was very significant to the needs of the society at that time, which required more trained manpower in the field of medicine (Rahman \& Sidek, 2017:464).

The field of astronomy flourished during the reign of Sultan Mehmed II (1451-1481) because at that time a center of astronomy called Muwaqqithana was 
officially established. The center operates in a small building located within the mosque grounds. It can be said that almost all the mosques in the municipalities in the Ottoman Empire had this school. The financing of its operations is based on the waqf system. Among the activities carried out are such as determining the time of prayer, setting the calendar and the direction of Qibla. During the reign of Sultan Murad III, a national observatory was built by a Turkish astronomer named Taqi Al-Din. The observatory was built in 1577.

With the observatory, studies in the field of astronomy became more widespread. The scope of the study has expanded to observations of comets, earthquakes, solar energy and eclipses. Sultan Murad III invested a lot in the field of astronomy because he was also very passionate in that field. He was the one who ordered that the observatory center be built immediately for the convenience of researchers. Upon completion, the center was run by eight researchers assisted by several clerks and research assistants. Among the important studies that have been done at the center is by improving the Astronomical Table that has been built by Ulugh Beg (originally from Haran, Turkey and died in 929). The center has also been equipped with library facilities that have always been a focus for astronomers and mathematicians (Rahman \& Sidek, 2017:466).

As Europe began to engage with the printing industry on a large scale, the Ottoman government still relied on the traditional production of books by producing manuscripts. The purpose is to provide employment opportunities to copyists, calligraphers and illumination painters (background). For that reason, until the $17^{\text {th }}$ century, a total of 80,000 workers were involved with the manuscript production industry (Pektas, 2015:9).

But that does not mean that the printing industry did not exist during the reign of Sultan Murad III. The printing industry in Turkey at that time remained fast moving but was dominated by non-Muslims. The Jews were the earliest people to open a printing company in Istanbul. Among them was Reyna who opened a printing company in Belvedere which was later managed by Joseph ben Yitzhak Ashkeloni between 1593 and 1597. Furthermore, Johannes Terznc'i was 
an Armenian who received a formal education in printing in Rome and Venice. He opened a printing company in Istanbul in 1587. Shortly afterwards, a Greek entrepreneur appeared, who opened a printing company in Istanbul. One of the earliest names was Nikodemos Metaxas. At that time, Arabic books were commonly printed outside Turkey. Among the most famous companies are such as Typographia Medicea which is located in Rome, Italy and was founded in 1584 (Pektas, 2015:13-19).

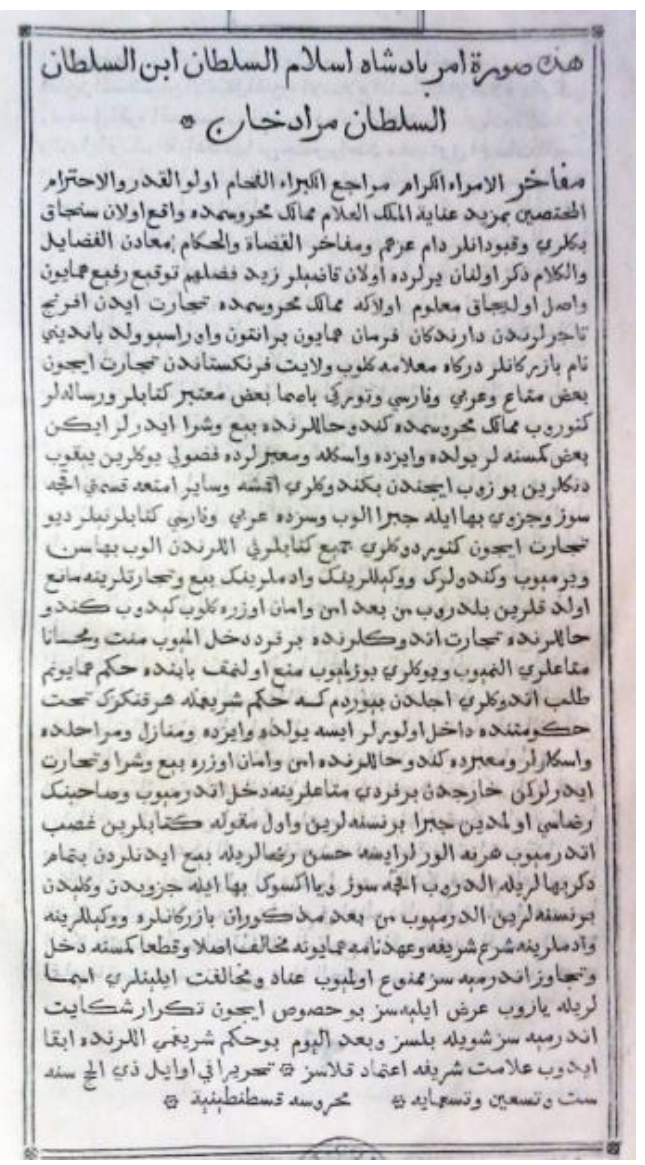

Figure 2: The name of Sultan Murad III printed in 1588 is in the British Library collection, marked with shelfmark G.7840.

These three industries are indeed very synonymous with Aceh in particular with regard to the Islamic boarding school, famous known as Dayah, a center of higher education for the local children. With the establishment of bilateral relations between Indonesia and Turkey, the industry is growing rapidly in Aceh 
when the industry is included in the curriculum of Islamic boarding school. For example, a medical book entitled Aceh Al-Rahmah fi al-Tibb wa al-Hikmah was written by Shaykh Abbas Kuta Karang who founded Dayah Ulee Susu. The book, which was first written in 1849 , was also influenced by Turkish elements. Among them is the story of King Kisra who talked to four doctors from the Iraqi nation, Rumi (Turkey), Hindi and Sawadi,

"So said the doctor Rumi, starting a medicine that has no disease in it that is eaten habb al-rashad seeds every day for a while" (Karang, 2017:110-111).

Among the names of figures used as reference in the writing are such as Ibn Hubal (1117-1215), Abu Amar Uthman ibn Abdul Rahman Salahuddin AlKurdi Al-Sharazuri (1181-1245), Musharrifudin Al-Sa'di (1213- 1291), Kamaluddin Al-Damiri (1344-1405). References to these names are certainly found in most of the manuscripts produced during the Ottoman period (Karang, 2017:45, 65, 178, 197).

Astronomy is a very important branch of knowledge in the dayah curriculum because it is closely related to the field of fiqh. This is because astronomy is very useful to observe the crescent moon to determine the beginning of the month, especially the date of the beginning of fasting, and Eid, the direction of Qibla and determining the time of prayer. Due to the importance of this knowledge in the field of religion, then it has become the main subjects at the University of Baitul Rahman and Baitul Rahim in the $16^{\text {th }}$ century in Aceh. It is not impossible that this knowledge has been brought in by Turkish scholars and scientists and then absorbed in the syllabus of dayah and universities.

Sheikh Abbas Kuta Karang also wrote a treatise on astronomy with the title Siraj Al-Zalam fi Ma'rifat al-Sa'di wa Al-Nahas fi Suhur wa Al-Ayyam (Dark Light to know the count of months and days). Its content revolves around the determination of the beginning of the month in the Hijri calendar and its effect on the perfection of worship in fasting, Eid and Hajj. Also included in the content is the method of choosing a good day to do an activity in order to receive blessings 
from Allah SWT. The method is based on the calculation of date and time according to the Hijri calendar (Mubarrak, 2017:11).

As a Turkish astronomer who tend to use the method of calculation based on the zij Ulugh Beg, so too is the case with Indonesia including Aceh scholars; who are on average more familiar with the calculation method. The method using the geocentric theory is also very popularly taught by the scholars in Makkah and Egypt. In the writing of the books of astronomy, there are two approaches used which are known as hisab urfi, and hisab haqiqi. The method of calculation in urfi calculation is based on local customs and traditions. While hisab haqiqi takes into account the actual position of an object that is calculated. Usually it uses Epoch theory (mabda ') and its calculation center is adjusted according to the location of its compiler (Jani, Sulong, \& Aziz, 2016:42-43).

Just as Turkey, Aceh is considered a factory producing the manuscript in the $16^{\text {th }}$ century and $17^{\text {th }}$ century AD. About its direct relationship with Turkey can be seen from two aspects. First, the names of the figures referenced in the manuscript Aceh and second, the type of paper used for the production of the manuscript. Hamzah Fansuri, a figure believed to have had the greatest influence in the situation of debates on the issue of a'yan thabitah with foreign scholars who came during the time of Sultan Alauddin Mansur Shah, was heavily influenced by the famous big names in Turkey. In an article entitled Al-Muntahi, Hamzah refers to big Turkish names such as Jalaluddin Muhammad Rumi (1207-1273) and Nuruddin Abdul Rahman Jami '(1414-1492) (Al-Attas, 1970:14).

Apart from that, Hamzah also refers a lot to the names of great Persian and Andalusian figures who are also famous in Central Asia and Europe including Turkey. It is not impossible that at that time, the Ottoman Government exported many Sufi manuscripts as Sultan Murad III and Sultan Alauddin Mansur Shah shared the same interests. As contained in the manuscript collection at Dayah Tanoh Abee, Aceh Besar; most of the manuscripts produced in Aceh, is a European paper, which has a picture of a smiling crescent moon background. 
Most likely, the papers had been exported with a large quantity to Aceh by Turkey of the past (Fathurahman, 2010).

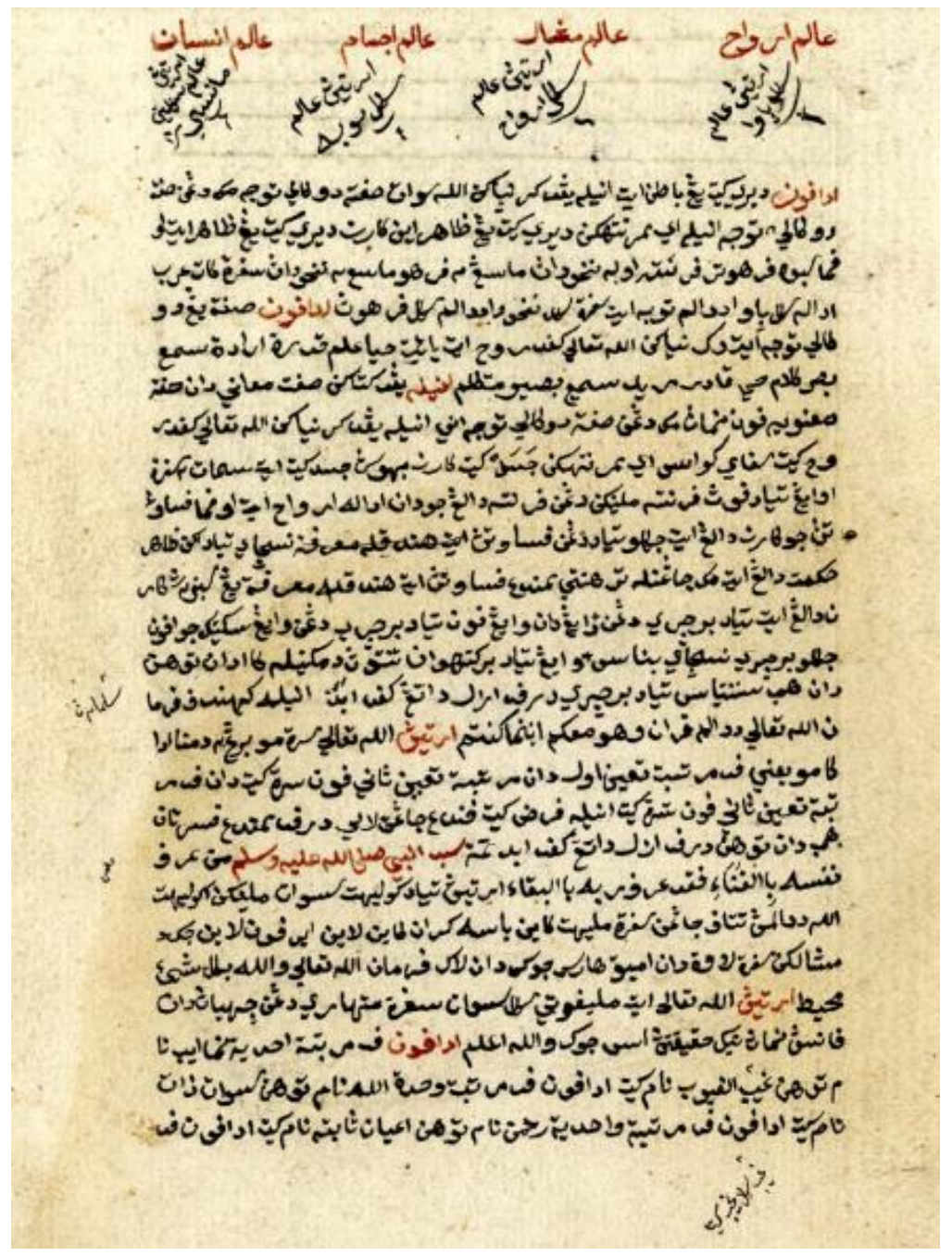

Figure 3: Examples of Malay manuscripts that use Malay-Jawi language. This manuscript is labeled as MS 511 Kitab Tauhid, and is currently kept in the Manuscript Collection of the National Library of Malaysia, Kuala Lumpur

Similar to the tragedy that befell Sultan Alaudin Mansur Shah, Sultan Murad III was also assassinated through an enemy conspiracy that infiltrated the kingdom. The events of his assassination took place in 1594 as a result of evil plans abroad and within the country who were envious of his wisdom in dealing 
with peace, and the conquest of European and Middle Eastern countries. After his death, Turkey experienced chaos throughout the country (Abbas, 2007:28).

Table 1 Comparison between the reign of Sultan Alaudin Mansur Shah and Sultan Murad III

\begin{tabular}{|l|l|l|}
\hline Item & \multicolumn{1}{|c|}{$\begin{array}{c}\text { Sultan Alaudin Mansur } \\
\text { Shah }\end{array}$} & \multicolumn{1}{|c|}{ Sultan Murad III } \\
\hline Knowledge & $\begin{array}{l}\text { Very fond of gathering } \\
\text { with religious scholars. } \\
\text { Many foreign scholars } \\
\text { came during his reign }\end{array}$ & $\begin{array}{l}\text { Very fond of } \\
\text { coexisting with } \\
\text { scholars and scientists }\end{array}$ \\
\hline $\begin{array}{l}\text { Intellectual } \\
\text { Development }\end{array}$ & $\begin{array}{l}\text { Build many schools for } \\
\text { the purpose of } \\
\text { disseminating knowledge }\end{array}$ & $\begin{array}{l}\text { Build many research } \\
\text { centers and study } \\
\text { centers to advance a } \\
\text { field of knowledge }\end{array}$ \\
\hline Manuscript Production & $\begin{array}{l}\text { Encourage scholars to } \\
\text { write books to solve } \\
\text { society's problems }\end{array}$ & $\begin{array}{l}\text { Provides many job } \\
\text { opportunities to } \\
\text { writers, copyists, } \\
\text { calligraphers and } \\
\text { illumination painters }\end{array}$ \\
\hline Trade & $\begin{array}{l}\text { Reopening the spice trade } \\
\text { route from the } \\
\text { archipelago to Europe }\end{array}$ & $\begin{array}{l}\text { Enter into trade } \\
\text { agreements with } \\
\text { European countries }\end{array}$ \\
\hline Expansion of power & $\begin{array}{l}\text { Controlled almost the } \\
\text { whole of Sumatra and } \\
\text { Malay Peninsular }\end{array}$ & $\begin{array}{l}\text { Dominate Europe and } \\
\text { the Middle East }\end{array}$ \\
\hline Death & $\begin{array}{l}\text { He was killed because of } \\
\text { a power struggle }\end{array}$ & $\begin{array}{l}\text { He was assassinated } \\
\text { through a conspiracy } \\
\text { of enemies who were } \\
\text { jealous of the success } \\
\text { of the Ottoman } \\
\text { expansion of power, } \\
\text { and peace treaties } \\
\text { with several } \\
\text { European countries. }\end{array}$ \\
\hline
\end{tabular}

\section{CONCLUSION}

Diplomatic relations between Aceh and Turkey's long-standing relationship since the days of Sultan Salahuddin seen very important from two aspects. First, efforts to suppress the active Christianization movement were 
carried out by the Portuguese. Second, to safeguard the sovereignty, and welfare of Muslims. The first aspect is seen as very important because the cunning Portuguese mobilized the mission of Christianization of the locals by way of entering the islands within the archipelago such as Ambon and Maluku. The locals were then trained to use weapons and absorbed into the Portuguese army. They are the ones who later became a Portuguese naval involved in the war against Aceh. In attacks carried out by Sultan Alauddin Mansur Shah of Malacca, reported that the local people themselves have come down to help the Portuguese against Aceh (Subrahmanyam 2009:42-44).

The second aspect is divided into two main movements. First, reviving the trade routes of the Muslims from East to West. After the Portuguese took control of important ports such as Melaka, Goa and Cape of Good Hope; almost the entire trade route was monopolized by the Europeans. Only after Aceh in cooperation with Turkey, then the merchandise owned by Muslims, can be traded back in the Mediterannean Sea. Second, to protect the ships of the pilgrims and the merchant ships of the Muslims, from being disturbed by the Portuguese along the Indian Ocean and the Red Sea.

Diplomatic relations that were established between the government of Aceh and Turkey allows Aceh's naval empowered with weapons and high-tech cannon. The power of being owned by the navy of Aceh had frightened the Portuguese based in Goa, India. Without delay, the Secretary General of the Portuguese in Goa named Jorge de Lemos had expressed concerns about the strength of Aceh, when he made a statement to Lisbon in 1585 . He then asked the Portuguese government sent reinforcements to bolster their ranks in the archipelago (Rahim, Nadzri, Wahab, \& Zaki, 2015:33-34).

In summary, Sultan Alauddin Mansur Shah not only successfully continues diplomatic relations between Aceh and Turkey, as was done by the previous ruler of Aceh. But what is most important than that is the widening of Turkish influence in the government of Aceh. In addition to the recognition of the Ottoman Empire to the sultanate of Aceh as a superpower in charge of Islamic 
sovereignty and welfare of the Muslims in the East; technology transfer in the form of engineering, construction and armament of the Ottoman Empire to Aceh, had resulted Aceh considered on par with the great European powers of the period. 


\section{REFERENCES}

Abbas, E. M. (2007). Sultan 'Abd Al-Hamid II dan Kejatuhan Khilafah Islamiah (Peranan Gerakan Nasionalis \& Golongan Minoriti). Kuala Lumpur: Pustaka Salam.

Al-Attas, S. M. (1970). The Mysticism of Hamzah Fansuri. Kuala Lumpur: University of Malaya Press.

Arshad, I. S. (2004). kekuasaan Portugis di Timur dan Hubungannya dengan Kerajaan Uthmaniyyah. In F. M. Zain (Ed.), Khilafah Islamiyyah dan Masyarakat Melayu (pp. 1-17). Bangi: Jabatan Pengajian Arab dan Tamadun Islam Fakulti Pengajian Islam Universiti Kebangsaan Malaysia.

B1. (2011, November 29). Keturunan Portugis di Aceh. Retrieved March 21, 2021, from Berita Satu: www-beritasatu-com.cdn.ampproject.org

Bastoni, H. A. (2008). Sejarah Para Khalifah. Jakarta: Pustaka Al-Kautsar.

Batubara, T. (2020). Sultan Alauddin Riayat Syah Al-Qahhar: Sang Penakluk dari Kesultanan Aceh Darussalam. Jurnal Kajian Islam Kontemporer , 1 (1), 16.

Burhanudin, J. (2016). Pasang Surut Hubungan Aceh dan Turki Usmani: Perspektif Sejarah. Studia Islamika, Vol. 23, No. 2, 2016,23 (2), 373-389.

Casale, G. (2007). Global Politics in the 1580s: One Canal, Twenty Thousand Cannibals, and an Ottoman Plot to Rule the World. Journal of World History , 18 (3), 267-296.

Damhuri, E. (2020, June 13). Jejak Makam Ulama-Pejuang Turki Utsmani di Aceh. Retrieved March 21, 2021, from Republika.co.id: https://www.aa.com.tr/id/nasional/meneropong-jejak-makam-turkiutsmani-diaceh/1561954

Djajadiningrat, R. H. (1982). Kesultanan Aceh. (T. Hamid, Trans.) Aceh: Departemen Pendidikan dan Kebudayaan Proyek Pengembangan Permuseuman Daerah Istimewa Aceh. 
Fathurahman, O. (2010). Katalog Naskah Dayah Tanoh Abee Aceh Besar. (A. Toru, A. Kazuhiro, S. Yumi, \& S. A. Muthalib, Eds.) Jakarta: Komunitas Bambu.

Fikrie, M., \& Azis, M. A. (2017, November 29). Telusur Jejak Turunan Portugis di Aceh. Retrieved March 21, 2021, from Lokadata: amp-lokadataid.cdn.ampproject.org

Hassan, Z. (2004). Hubungan Alam Melayu dengan Kerajaan Uthmaniyyah: Tumpuan Terhadap Perbincangan Kitab Hadiqat Al-Azhar wa Al-Riyahin oleh Shaykh Ahmad Al-Fatani. In F. M. Zain (Ed.), Khilafah Islamiyyah dan Masyarakat Melayu (pp. 35-57). Bangi: Jabatan Pengajian Arab dan Tamadun Melayu Islam Fakulti Pengajian Islam Universiti Kebangsaan Malaysia.

Jani, M. F., Sulong, J., \& Aziz, A. H. (2016). Sumbangan Kitab Sullam Nayyirain dalam Hitungan Gerhana di Nusantara. Jurnal Al-Tamaddun , 11 (1), 3548 .

Karang, A. K. (2017). Kitab Perubatan Melayu Al-Rahmah fi Al-Tibb wa AlHikmah. (M. A. Shafri, \& H. M. Yahya, Trans.) Kuala Lumpur: Akademi Jawi Malaysia.

Maksudoglu, M. (1999). Osmanli History 1289-1922 Based on Osmanli Sources. Gombak: Research Centre International Islamic University Malaysia.

Melihat Jejak Turki di Gampong Bitai. (2021). Retrieved March 21, 2021, from Banda Aceh Tourism: bandaacehtourism.com

Mubarrak, H. (2017). From Aceh for Nusantara: The Contribution of 18th Century Acehnese Ulamas Work in the Integration of Science. Heritage of Nusantara , 6 (1), 1-20.

Nasir, R. Y. (2010, August 6). Gampoeng Turki itu bernama Bitai. Retrieved March 21, 2021, from Kompasiana.com: wwwkompasiana.com.cdn.ampproject.org 
Ozay, M. (2011). The Sultanate of Aceh Darussalam as a Constructive Power. International Journal of Humanities and Social Science , 1 (11), 274-283.

Pektas, N. (2015). The Beginnings of Pronting in the Ottoman Capital: Book Production and Circulation in Early Modern Istanbul. Osmanli Bilimi Arasturmalari , XVI (2), 3-32.

Rahim, R. A., Nadzri, A. b., Wahab, A. A., \& Zaki, A. F. (2015). Relasi Aceh dan Turki dalam Islamisasi Dunia Melayu: Suatu Analisis. Kontekstualita , 30 (1), 25-47.

Rahman, A. S., \& Sidek, R. S. (2017). Role and Contribution of Ottoman Science Institutions in the Development of Muslim Civilization: Spotlight on 16th Century. International Journal of Academic Research in Business and Social Sciences , 7 (8), 462-468.

Saputro, L. (2017, April 13). Bagaimana Turki Utsmani dekat dengan Aceh di Masa Lampau. Retrieved March 21, 2021, from GoodNews From Indonesia: www-goodnewsfromindonesia-id.cdn.ampproject.org

Subrahmanyam, S. (2009). Pulverised in Aceh: On Luis Monteiro Coutinho and his Martyrdom. Archipel , 78, 19-60.

Villers, J. (2001). Aceh, Melaka \& the Hystoria dos cercos de Malaca of Jorge de Lemos. Portuegese Studies, 17 (Homage to Charles Boxer), 75-85.

Winstedt, R. O., \& Wilkinson, R. J. (1974). A History of Perak. Kuala Lumpur: The Malaysian Branch of the Royal Asiatic Society.

Yusof, H. (2020, October 30). Malakat Tribune. Retrieved March 22, 2021, from Kisah cara Sultan Iskandar Thani menunjukkan kecintaannya pada Rasulullah SAW: https://www.malakattribunenews.com/2020/10/kisahcara-sultan-iskandar-thani-menunjukkan-kecintaannya-pada-rasulullah/

Zainuddin, H. M. (1957). Singa Atjeh Biographi Seri Sulthan Iskandar Muda. Medan: Penerbit Iskandar Muda.

Zainuddin, H. (1962). Tarich Atjeh dan Nusantara. Medan: Pustaka Iskandar Muda. 